\section{The Interaction Effect of Carbon Dioxide and Ethylene in the Storage Atmosphere on Potato Fry Color Is Dose-related}

\author{
Barbara J. Daniels-Lake ${ }^{1}$ and Robert K. Prange \\ Agriculture and Agri-Food Canada, Atlantic Food and Horticulture \\ Research Centre, 32 Main Street, Kentville, Nova Scotia B4N 1 J5 Canada
}

Additional index words. Solanum tuberosum, potato storage, fry color, modified atmosphere, $\mathrm{CO}_{2}$

\begin{abstract}
Previous studies have shown that the fry color of stored potatoes (Solanum tuberosum L.) can be negatively affected by an interaction between elevated $\mathrm{CO}_{2}(2 \mathrm{kPa})$ and ethylene gas $\left(0.5 \mu \mathrm{L} \cdot \mathrm{L}^{-1}\right)$ from various sources. Two consecutive trials were conducted during each of two storage seasons (2006 and 2007) to study the effects of varying concentrations of these two gases. In each year, $\mathrm{CO}_{2}$ at $0,0.5,1.0$, or $2.0 \mathrm{kPa}$ plus $0,0.25$, or $0.5 \mu \mathrm{L} \cdot \mathrm{L}^{-1}$ ethylene was applied in a factorial design to 'Russet Burbank' tubers for 9 weeks. Trials that began in Jan. 2006 and Jan. 2007 comprised the dormanttuber experiment; trials that began in Apr. 2006 and Apr. 2007 comprised the nondormant-tuber experiment. Fry color of the tubers was evaluated at the start of each trial and thereafter at intervals of 3 weeks. In all trials, when tubers were exposed to different concentrations of $\mathrm{CO}_{2}$ but without ethylene, fry color was the same as in untreated controls. When only ethylene was applied, the fry color was 7 to 22 Agtron percent reflectance units darker than the controls. In the nondormant-tuber experiment, the darkening resulting from ethylene was dose-related, in agreement with previous research. When the tubers were exposed to both $\mathrm{CO}_{2}$ and ethylene, dose-related responses to both gases were observed in the nondormant-tuber experiment, i.e., fry color was darker with an increase in either $\mathrm{CO}_{2}$ or ethylene when both gases were present. Neither the dose-response to ethylene nor the interaction between ethylene and $\mathrm{CO}_{2}$ was statistically significant in the dormant-tuber experiment. In both experiments, the darkest color was observed when both gases were present at the highest concentrations. A dose-response of potato fry color to $\mathrm{CO}_{2}$ in the presence of ethylene has not been reported previously.
\end{abstract}

The importance of light fry color to the potato (Solanum tuberosum L.) processing industry cannot be overstated. Because most of the North American potato crop must be stored for many months between harvest and processing, it is important to maintain the frying quality of the stored tubers throughout their storage term. Fry color, which is directly dependent on the concentration of reducing sugars in the tuber tissue (Burton et al., 1992; Mazza, 1983), is one of the most important quality attributes of processing tubers. It can be affected by various factors during the storage term.

During long-term storage, the $\mathrm{CO}_{2}$ concentration may increase considerably in the storage atmosphere. The major sources of

Received for publication 26 Feb. 2009. Accepted for publication 18 June 2009.

Contribution \# 2370, Atlantic Food and Horticulture Research Centre, Agriculture and Agri-Food Canada.

We thank S. Fillmore for expert guidance in statistics; P. Struik, J. Delong, and K. Pruski for reviewing the manuscript; and K. Hiltz, S. Bishop, and K. Munro Pennell for technical assistance.

${ }^{1}$ To whom reprint requests should be addressed; e-mail Barbara.Daniels-Lake@agr.gc.ca.
$\mathrm{CO}_{2}$ are tuber respiration and exhaust from internal combustion engines. Reported peak $\mathrm{CO}_{2}$ concentrations in ventilated potato stores range from 0.6 to $14 \mathrm{kPa}\left(\mathrm{CO}_{2}\right.$ quantities in $\mathrm{kPa}$ can be approximated as percentages) (Mazza and Siemens, 1990; Schaper et al., 1993). It is recommended that the $\mathrm{CO}_{2}$ concentration should be maintained below $1 \mathrm{kPa}$ in potato storage atmospheres (Rastovski, 1987; Schaper et al., 1993). The reported effects of elevated $\mathrm{CO}_{2}$ on tuber fry color vary widely. Some researchers have demonstrated that 2 to $5 \mathrm{kPa} \mathrm{CO}$ prevents increases in tuber sugars or does not darken fry color (Blankson, 1988; Daniels-Lake et al., 2005b; Denny and Thornton 1940). Others have shown that 0.5 to $15 \mathrm{kPa} \mathrm{CO}$ increases reducing sugar concentrations and/ or darkens fry color compared with tubers stored at ambient concentrations of $\mathrm{CO}_{2}$ (Khanbari and Thompson, 1994, 1996; Mazza and Siemens, 1990; Schouten, 1993). Season-long monitoring of several commercial stores revealed no correlation between the measured $\mathrm{CO}_{2}$ concentrations and observed fry color changes (J. Walsh, personal communication).

In contrast, ethylene gas in the storage atmosphere is one of several factors that are known to cause darkening of potato fry color during storage (Daniels-Lake et al., 2005a; Denny and Thornton, 1940; Duncan, 1999; Prange et al., 1998). The effect is dosedependent, i.e., darkening increases as the concentration rises with saturation of the effect in the range of 1 to $10 \mu \mathrm{L} \cdot \mathrm{L}^{-1}$ depending on cultivar (ethylene concentrations in $\mu \mathrm{L} \cdot \mathrm{L}^{-1}$ can be approximated as parts per million, volume per volume) (Daniels-Lake et al., 2005a). Significant sources of ethylene in the storage atmosphere include pathogens, engine exhaust from equipment or vehicles, climacteric fruit stored nearby, and as a byproduct of chlorpropham sprout inhibitor application (Duncan, 1999). Potato tubers naturally produce small quantities of ethylene; sprouting and stresses such as disease and injury increase the production rate (Creech et al., 1973; Korableva and Ladyzhenskaya, 1995; McGlasson, 1969; Poapst et al., 1968; Suttle, 2003). If ventilation is restricted within the pile, or reduced for operational reasons, both ethylene and $\mathrm{CO}_{2}$ gases can accumulate in the potato storage atmosphere. Apart from instances in which ethylene gas is used as a sprout suppressant or is a contaminant from chlorpropham application, there is little information on actual concentrations of ethylene gas in commercial potato storage atmospheres. Preliminary investigations suggest that ethylene concentrations of 0.1 to $2 \mu \mathrm{L} \cdot \mathrm{L}^{-1}$ are not unusual (B. Daniels-Lake, unpublished data).

Although up to $2 \mathrm{kPa} \mathrm{CO}_{2}$ has little effect on fry color by itself, when combined with ethylene, the darkening effect resulting from ethylene is increased (Daniels-Lake et al., 2005 b, 2008). Storage operators can reduce the risk to their stored potatoes from this potential interaction by ventilating to keep the concentrations of both gases low throughout the storage term. However, there is no published information regarding threshold concentrations, i.e., how low the concentrations of these two gas should be, to prevent their interaction affecting the fry color of the stored tubers.

Studies were initiated at the potato postharvest physiology facilities at Agriculture and Agri-Food Canada's Atlantic Food and Horticulture Research Center (AFHRC) in Kentville, Nova Scotia, Canada, to evaluate the effect on potato fry color of combinations of various concentrations of $\mathrm{CO}_{2}$ and ethylene gas. One of the goals of this work was to search for threshold concentrations below which the combination of these two gases does not darken potato fry color.

\section{Materials and Methods}

Trials were conducted from January to June during 2 consecutive years, 2006 and 2007. In each year, commercially grown 'Russet Burbank' potatoes harvested in midOctober were obtained soon after harvest from four different commercial potato growers located in eastern Canada. To permit suberization and wound healing, the tubers were held for 4 weeks at $13{ }^{\circ} \mathrm{C}$ and then 
cooled at a rate of $1{ }^{\circ} \mathrm{C}$ per week to $9^{\circ} \mathrm{C}$. All tubers used in the trials were dipped in early December in a $1 \%$ a.i. water emulsion of chlorpropham [Sprout-Nip EC, isopropyl n(3-chlorophenyl) carbamate, $320 \mathrm{~g} \cdot \mathrm{L}^{-1}$ a.i.; Stanchem Inc., Etobicoke, Ontario, Canada; CIPC] sprout inhibitor and allowed to air-dry. Because previous studies have suggested that the response to the $\mathrm{CO}_{2}$ and ethylene interaction may be stronger in nondormant than in dormant tubers (Daniels-Lake et al., 2005b, 2008), the trials were divided into two experiments to separately evaluate tubers in these physiologically distinct states. In each year, two consecutive 9-week trials were conducted, i.e., 10 Jan. to 21 Mar. and 18 Apr. to 20 June in 2006, and 16 Jan. to 19 Mar. and 17 Apr. to 19 June in 2007. The two trials that started in January comprised the dormant experiment, and the two trials that started in April comprised the nondormant experiment. Only sprout-inhibited tubers were included in the trials to retain the focus on the effects of $\mathrm{CO}_{2}$ and ethylene on fry color. Additional tubers from the same sources but which had not been treated with CIPC were stored in common storage at $9{ }^{\circ} \mathrm{C}$ until June of each year and were monitored for sprouting as an indicator of the dormancy status of the material used in the trials.

Samples weighing $\approx 2 \mathrm{~kg}$ (10 tubers) were placed in mesh bags and stored during the trials in $0.1-\mathrm{m}^{3}$ sealed aluminum chambers (constructed locally). Two sets of 12 chambers were used; each gas treatment was delivered to one chamber in each set. Two of the four source lots of potatoes were assigned to each set of chambers. At the start of each trial, each chamber held six samples (three samples from each of two sources) predesignated for specific evaluation dates. The chambers were placed in a refrigerated cold room, which maintained the temperature at $9 \pm 0.3{ }^{\circ} \mathrm{C}$.

The chamber atmospheres were modified with medical-grade compressed air (Praxair Inc., Dartmouth, Nova Scotia, Canada) plus $0,0.5,1$, or $2 \mathrm{kPa} \mathrm{CO}_{2}$ (Praxair Inc.) and 0 , 0.25 , or $0.5 \mu \mathrm{L} \cdot \mathrm{L}^{-1}$ ethylene gas (Praxair Inc.) in a factorial arrangement. Three times per day the chamber atmospheres were flushed for $60 \mathrm{~min}$ at $\approx 2 \mathrm{~L} \cdot \mathrm{min}^{-1}$ with appropriate compressed gas mixtures to maintain the desired gas concentrations and replenish consumed $\mathrm{O}_{2}$. The gas delivery apparatus was as described in Daniels-Lake et al. (2005b). Control chambers $\left(0 \mathrm{CO}_{2}\right.$ and 0 ethylene) were flushed with unamended compressed air. A paper sack containing $\approx 0.5 \mathrm{~kg}$ of hydrated lime $\left[\mathrm{Ca}(\mathrm{OH})_{2}\right.$; Graymont (QC) Inc., Boucherville, Quebec, Canada] was placed inside the $0 \mathrm{CO}_{2}$ chambers to scrub ambient and respired $\mathrm{CO}_{2}$.

$\mathrm{O}_{2}$ and $\mathrm{CO}_{2}$ concentrations were measured several times per week using a handheld gas monitor (CheckPoint; PBI Dansensor America, Glen Rock, NJ). Ethylene concentrations were continuously monitored using an automated system as described in Daniels-Lake et al. (2005b). Gas delivery flow-rates were adjusted manually as needed to maintain the desired gas concentrations in the chambers. Oxygen in the chamber atmospheres was consistently $20 \mathrm{kPa}$ or higher. Carbon dioxide and ethylene were maintained within $10 \%$ and $20 \%$, respectively, of the desired treatment concentrations.

An open plastic jar, $6 \mathrm{~cm}$ in diameter and containing $\approx 300 \mathrm{~mL}$ of distilled water, was placed inside each chamber to help maintain high humidity. The relative humidity $(\mathrm{RH})$ inside the chambers was checked several times per week, and remained at $95 \%$ to $99 \% \mathrm{RH}$.

The fry color of three samples of 10 tubers from each source was evaluated in early November of each year (shortly after arrival at AFHRC) and at the start of each trial in January or April. The fry color of one 10tuber sample from each source $\times$ treatment combination (four sources $\times 12$ treatments) was evaluated at 3,6, and 9 weeks during each trial using the methods described in Daniels-Lake et al. (2005b). Fry color scores in Agtron percent reflectance units (ARu) were based on a scale of 0 to 100 representing the calibration range from black to very pale gray, respectively.

The customized experimental design was a replicated two-way factorial with a split plot arrangement. The main plot was treatment $\left(\mathrm{CO}_{2} \times\right.$ ethylene $)$ and the subplot was evaluation date. Experiments were replicated physically by using potatoes of the same cultivar from four separate growers each year and replicated in time by conducting the trials in 2 different years. The data for both years were combined for statistical analysis by analysis of variance using Genstat statistical software (Genstat Committee, 2008). Orthogonal and polynomial contrasts were used to determine differences across treatments, levels of treatments, and evaluation times. This provided insight into the pattern of the responses in addition to identifying differences between specific treatments. In all analyses, differences were considered significant if $P \leq 0.05$.

\section{Results and Discussion}

Within each year, all tubers used in both trials had been treated with CIPC sprout inhibitor on the same date; these tubers did not sprout during either trial. In January of each trial year, the extra tubers that had not been treated with CIPC were not yet sprouting and therefore considered to be still dormant. In contrast, in April of each year, dormancy had ended and these tubers were sprouting vigorously (data not presented). This reflects the long dormancy of the Russet Burbank cultivar.

Mean tuber fry color on arrival AFHRC was $69.5 \pm 5.4($ mean $\pm \mathrm{SD}, \mathrm{n}=4)$ and $65.5 \pm$ 6.9 ARu in 2006 and 2007, respectively. This reflects normal variation attributable to growing seasons and production factors, including differences in maturity.

In the dormant experiment, the main effects on fry color of $\mathrm{CO}_{2}$, ethylene, and evaluation date (time) were significant $(P=0.014, P<$ 0.001 , and $P<0.001$, respectively). The interaction of ethylene and evaluation date was also significant (quadratic ethylene $\times$ quadratic evaluation date, $P=0.011$ ), whereas other interactions were not significant.

The statistical main effect of $\mathrm{CO}_{2}$ on fry color in the dormant experiment, although significant, appears to be associated with the effect of the ethylene in some of the treatments included in these means, because the fry color of tubers exposed to $\mathrm{CO}_{2}$ without ethylene was the same at all levels of $\mathrm{CO}_{2}$ treatment (Fig. 1). This is consistent with previous findings regarding fry color of tubers exposed to 0.5 and $2 \mathrm{kPa} \mathrm{CO}_{2}$ without ethylene (Daniels-Lake et al., 2005b, 2008).

The fry color of tubers exposed to ethylene in the dormant experiment was darker than the fry color of tubers not exposed to ethylene (71.8, 64.5, and 61.8 $\mathrm{ARu}$ in $0,0.25$, and $0.5 \mu \mathrm{L} \cdot \mathrm{L}^{-1}$ ethylene, respectively; Table 1; Fig. 1). However, the response was similar at the two ethylene concentrations. Darkening attributable to ethylene was apparent at all levels of $\mathrm{CO}_{2}$ treatment (Fig. 1), which is consistent with previous findings (DanielsLake et al., 2005b). Although the $\mathrm{CO}_{2} \times$ ethylene interaction was not statistically significant $(P=0.691)$ in the dormant experiment, two trends were suggested by the data: fry color darkening in response to $\mathrm{CO}_{2}$ only when ethylene was also present, and a doseresponse to $\mathrm{CO}_{2}$ when the gases were applied together (Fig. 1).

Fry color was progressively lighter (i.e., higher color scores) at successive evaluation dates in the dormant experiment (Table 1). Mean fry color was 65.0, 65.5, and 67.6 ARu at 3, 6, and 9 weeks, respectively. This is mainly attributable to declining hexose concentrations with increasing time, likely as a result of tuber respiration or conversion back to sucrose (Isherwood, 1973; Parkin and Schwobe, 1990).

In the dormant experiment, the fry color of tubers that were not exposed to ethylene had progressively lighter fry color from 0 to 9 weeks (Table 1). In contrast, the tubers exposed to ethylene had darker fry color at 3 weeks than at 0 weeks. Thereafter, the fry color of the ethylene-treated tubers also improved with increasing time. However, the fry color of ethylene-treated tubers remained darker than the fry color of tubers that were not exposed to ethylene throughout the dormant experiment (Table 1). The response to ethylene across time was similar at both concentrations. This is consistent with the work of other researchers, who reported progressive recovery of ethylene-darkened fry color with additional time in storage (Daniels-Lake et al., 2005a, 2007; Parkin and Schwobe, 1990; Prange et al., 1998).

In the nondormant experiment, the main effects on fry color of $\mathrm{CO}_{2}$, ethylene, and evaluation date (time) were significant $(P<$ $0.001, P<0.001$, and $P=0.029$, respectively) as was the interaction of $\mathrm{CO}_{2}$ and ethylene (linear $\mathrm{CO}_{2} \times$ quadratic ethylene, $P=0.011$ ). The other interactions were not significant.

Mean fry color in the nondormant trials improved with time (Table 1). The fry color 


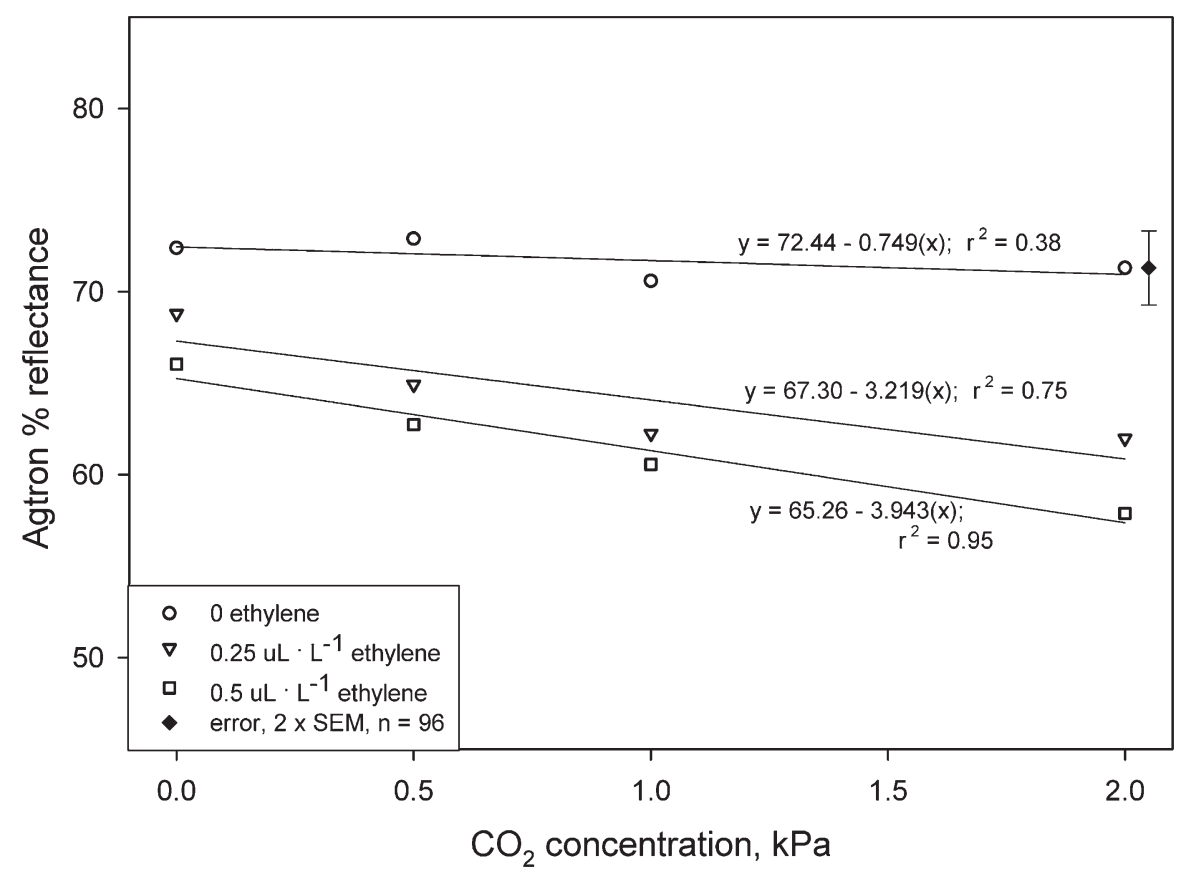

Fig. 1. Mean fry color of potato tubers stored for 9 weeks beginning in January (dormant experiment, 2006 and 2007 data combined) with various concentrations of $\mathrm{CO}_{2}$ and ethylene. Significant effects: $\mathrm{CO}_{2}(P=$ $0.014)$; ethylene $(P<0.001)$. Vertical bar represents $2 \times$ SEM.

Table 1. Fry color of potatoes stored with $\mathrm{CO}_{2}$ and/or ethylene gas for 9 weeks, means of 2006 and 2007 data.

\begin{tabular}{|c|c|c|c|c|c|}
\hline \multirow[b]{2}{*}{$\mathrm{CO}_{2}(\mathrm{kPa})$} & \multirow{2}{*}{$\begin{array}{l}\text { Ethylene } \\
\left(\mu \mathrm{L} \cdot \mathrm{L}^{-1}\right)\end{array}$} & \multicolumn{4}{|c|}{ Time after start of trials (weeks) } \\
\hline & & 0 & 3 & 6 & 9 \\
\hline \multicolumn{2}{|c|}{ Dormant expt. } & \multicolumn{4}{|c|}{ Agtron $\%$ reflectance units } \\
\hline \multirow[t]{3}{*}{0} & 0 & 69.5 & 71.8 & 71.7 & 73.7 \\
\hline & 0.25 & & 68.1 & 67.3 & 71.0 \\
\hline & 0.5 & & 64.8 & 65.8 & 67.5 \\
\hline \multirow[t]{3}{*}{0.5} & 0 & & 71.6 & 72.1 & 75.0 \\
\hline & 0.25 & & 65.7 & 63.1 & 66.0 \\
\hline & 0.5 & & 61.7 & 63.0 & 63.5 \\
\hline \multirow[t]{3}{*}{1} & 0 & & 68.2 & 70.8 & 72.7 \\
\hline & 0.25 & & 61.7 & 60.7 & 64.4 \\
\hline & 0.5 & & 59.5 & 60.7 & 61.6 \\
\hline 2 & 0 & & 70.1 & 71.2 & 72.6 \\
\hline & 0.25 & & 60.9 & 60.9 & 64.1 \\
\hline & 0.5 & & 55.7 & 58.8 & 59.1 \\
\hline \multicolumn{2}{|c|}{ Significant effects } & Ethylen & $\begin{array}{l}\mathrm{O}_{2}: P \\
\text { lene: } \\
\text { me: } P \\
\text { ladrati } \\
\text { er inte }\end{array}$ & $\begin{array}{l}=1.1 \\
\mathrm{M}=1 \\
\mathrm{I}=0.3 \\
\text { ): } P= \\
\text { signifi }\end{array}$ & $=2.288$ \\
\hline \multicolumn{6}{|c|}{ Nondormant expt. } \\
\hline \multirow[t]{3}{*}{0} & 0 & 76.7 & 77.8 & 81.6 & 80.4 \\
\hline & 0.25 & & 66.5 & 67.4 & 65.4 \\
\hline & 0.5 & & 56.2 & 58.9 & 58.3 \\
\hline \multirow[t]{3}{*}{0.5} & 0 & & 80.2 & 80.5 & 80.3 \\
\hline & 0.25 & & 64.0 & 63.1 & 65.4 \\
\hline & 0.5 & & 56.2 & 57.7 & 56.9 \\
\hline \multirow[t]{3}{*}{1} & 0 & & 79.7 & 78.7 & 81.1 \\
\hline & 0.25 & & 61.9 & 63.4 & 64.3 \\
\hline & 0.5 & & 55.4 & 57.8 & 55.9 \\
\hline \multirow[t]{4}{*}{2} & 0 & & 78.0 & 80.7 & 78.2 \\
\hline & 0.25 & & 57.9 & 57.0 & 59.7 \\
\hline & 0.5 & & 53.6 & 53.8 & 53.5 \\
\hline & Significant effects & \multicolumn{4}{|c|}{$\begin{array}{c}\text { Time: } P=0.029, \text { SEM }=0.324 \\
\mathrm{CO}_{2} \times \text { ethylene (linear } \times \text { quadratic): } P=0.003, \mathrm{SEM}=1.016 \\
\text { Other interactions not significant }\end{array}$} \\
\hline
\end{tabular}

of tubers exposed to ethylene darkened sharply from 0 to 3 weeks and remained much darker at 6 and 9 weeks than the controls (Table 1). However, the interaction of ethylene with time was not statistically significant $(P=0.495)$ in the nondormant experiment. The fry color darkening attributable to $0.5 \mu \mathrm{L} \cdot \mathrm{L}^{-1}$ ethylene was greater than to $0.25 \mu \mathrm{L} \cdot \mathrm{L}^{-1}$ ethylene, reflecting a dose-related response to the ethylene in the nondormant experiment (Table 1). This is consistent with the findings of Daniels-Lake et al. (2005a), who showed a dose-dependent relationship between darkening of fry color and exposure of tubers to ethylene concentrations of 0.4 and $4.0 \mu \mathrm{L} \cdot \mathrm{L}^{-1}$.

The response of fry color to $\mathrm{CO}_{2}$ in the nondormant experiment was dependent on whether ethylene was also present (Table 1; Fig. 2). The tuber fry color in all treatments with $\mathrm{CO}_{2}$ but without ethylene remained equivalent to the color of the control tubers. In contrast, tubers exposed to ethylene without $\mathrm{CO}_{2}$ had darker fry color than the controls or tubers exposed to $\mathrm{CO}_{2}$ only (Fig. 2). The dose-related response to ethylene concentration was apparent at all $\mathrm{CO}_{2}$ concentrations in the nondormant experiment. Tubers stored with both ethylene and $\mathrm{CO}_{2}$ had darker fry color than either the control tubers or the tubers exposed to $\mathrm{CO}_{2}$ only (Table 1; Fig. 2). At the highest $\mathrm{CO}_{2}$ concentration, the fry color of tubers stored with both gases had a darker fry color than with ethylene alone. The darkest fry color in the nondormant experiment was observed in tubers exposed to both gases at the highest concentrations. These observations indicate a dose-related response to both $\mathrm{CO}_{2}$ and ethylene. The response to $\mathrm{CO}_{2}$ increments was greater at 0.25 than at $0.5 \mu \mathrm{L} \cdot \mathrm{L}^{-1}$ ethylene as the different slopes for these two lines demonstrate (Fig. 2). This observation is intriguing, because it suggests that an additional factor may be involved. The gases appear to be interacting at the metabolic level, likely affecting respiration rate, starch-sucrose, or sucrose-hexose interconversion rates, and perhaps other enzymatic pathways.

The responses to the $\mathrm{CO}_{2}$ and ethylene treatments appeared to be somewhat different in the two experiments, which concurs with previous reports (Daniels-Lake et al., 2005b, 2008). The dormant and nondormant states are recognized as different as a result of progressive physiological aging of the tubers during long-term storage, even among CIPCtreated tubers when no sprouting is apparent. Physiological aging affects numerous aspects of tuber metabolism, including plant growth regulator concentrations, starch mobilization, respiration rate, sugars, membranes, activity and abundance of various enzymes, and gene activation. From the present work, it is not clear which of these were affected by exposure to the combination of $\mathrm{CO}_{2}$ and ethylene, except that the darkened fry color is evidence of elevated reducing sugars. Additional research is needed to elucidate the influence of the many factors involved in both dormant and nondormant tubers. 


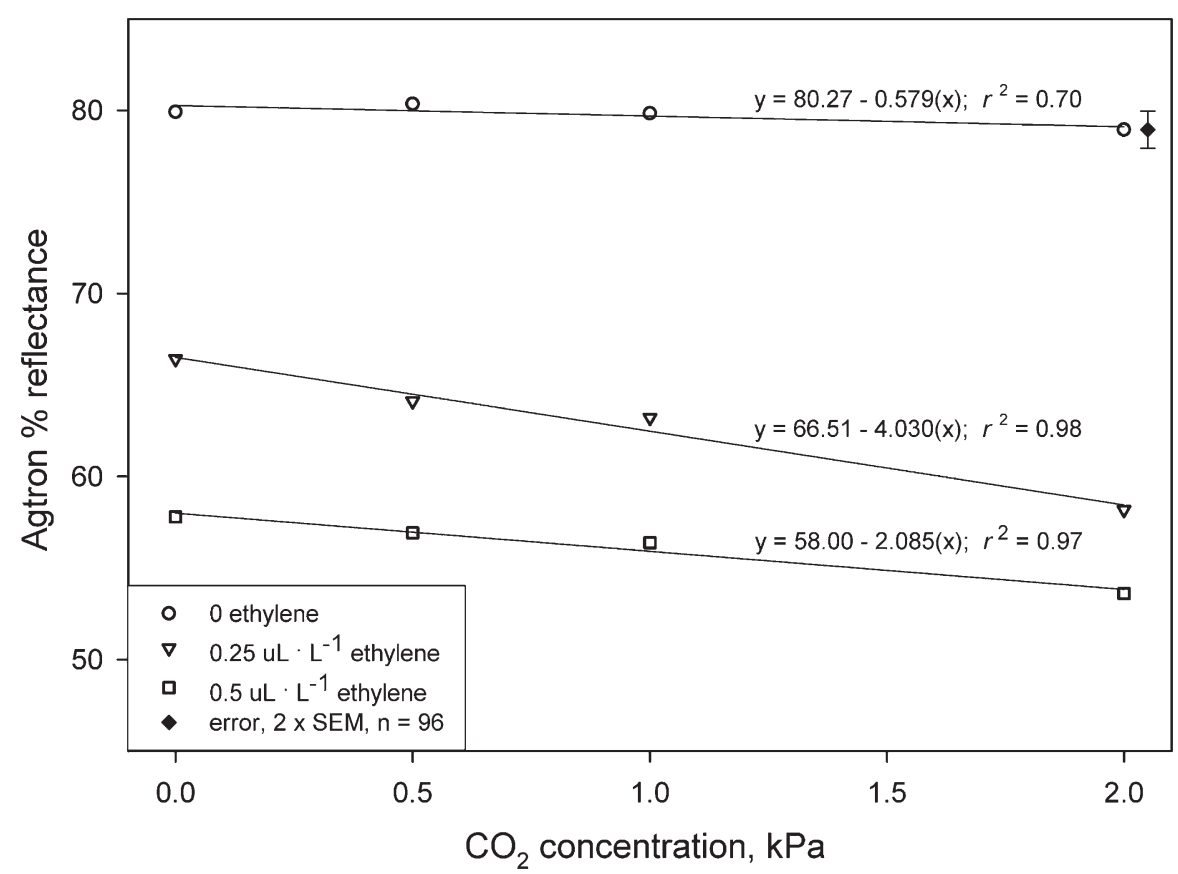

Fig. 2. Mean fry color of potato tubers stored for nine weeks beginning in April (nondormant experiment, 2006 and 2007 data combined) with various concentrations of $\mathrm{CO}_{2}$ and ethylene. Significant effects: $\mathrm{CO}_{2} \times$ ethylene (linear $\mathrm{CO}_{2} \times$ quadratic ethylene, $P=0.003$ ). Vertical bar represents $2 \times$ sEM.
Neither a threshold concentration (below which there was no effect on fry color) nor a saturation concentration (above which there was no additional effect on fry color) was identified for either gas within the concentration ranges applied in these experiments. Additional study is needed to determine these concentrations. Nevertheless, the results have clearly demonstrated that fry color can be affected by as little as $0.5 \mathrm{kPa} \mathrm{CO}$ when a trace concentration of ethylene is also present. Because the dose-response to $\mathrm{CO}_{2}$ in the presence of ethylene has not been reported previously, these results provide an important new factor for consideration by the potato processing industry to more effectively manage potato fry color during longterm storage.

\section{Literature Cited}

Blankson, J.E. 1988. Storage carbon dioxide and the chip color of several chipping potato cultivars. MSc thesis, University of Guelph,

Burton, W.G., A. van Es, and K.J. Hartmans. 1992. The physics and physiology of storage, p. 608Guelph, Ontario, Canada.

Duncan, H.J. 1999. Explosion and combustion processes associated with the fogging of stored potatoes. Potato Res. 42:25-29.

Genstat Committee. 2008. GenStat. 11th Ed. VSN International Ltd, Hemel Hempstead, UK.

Isherwood, F.A. 1973. Starch-sugar interconversion in Solanum tuberosum. Phytochemistry 12:2579-2591.

Khanbari, O.S. and A.K. Thompson. 1994. The effect of controlled atmosphere storage at $4{ }^{\circ} \mathrm{C}$ on crisp color and on sprout growth, rotting and weight loss of potato tubers. Potato Res. 37:291-300.

Khanbari, O.S. and A.K. Thompson. 1996. Effect of controlled atmosphere and cultivar on sprouting and processing quality of stored potatoes. Potato Res. 39:523-531.

Korableva, N.P. and É.P. Ladyzhenskaya. 1995. Mechanism of hormonal regulation of potato (Solanum tuberosum L.) tuber dormancy. Biochemistry 60:33-38.

Mazza, G. 1983. Correlations between quality parameters of potatoes during growth and long-term storage. Amer. Potato J. 60:145159.

Mazza, G. and A.J. Siemens. 1990. Carbon dioxide concentration in commercial potato storages and its effect on quality of tubers for processing. Amer. Potato J. 67:121-132.

McGlasson, W.B. 1969. Ethylene production by slices of green banana fruit and potato tuber tissue during the development of induced respiration. Aust. J. Biol. Sci. 22:489-491.

Parkin, K.L. and M.A. Schwobe. 1990. Effects of low temperature and modified atmosphere on sugar accumulation and chip colour in potatoes (Solanum tuberosum). J. Food Sci. 55:1341-1433.

727. In: Harris, P.M. (ed.). The potato crop: Chapman and Hall, London, UK.

Creech, D.L., M. Workman, and M.D. Harrison. 1973. The influence of storage factors on endogenous ethylene production by potato tubers. Amer. Potato J. 50:145-150.

Daniels-Lake, B.J., R.K. Prange, S.D. Bishop, and K. Hiltz. 2008. 1-Methylcyclopropene counteracts fry color darkening attributable to carbon dioxide and ethylene interaction. HortScience 43:2112-2114.

Daniels-Lake, B.J., R.K. Prange, W. Kalt, and J.R. Walsh. 2007. Methods to minimize the effect of ethylene sprout Inhibitor on potato fry colour. Potato Res. 49:303-326.

Daniels-Lake, B.J., R.K. Prange, J. Nowak, S.K. Asiedu, and J.R. Walsh. 2005a. Sprout development and processing quality changes in potato tubers stored under ethylene: 1. Effects of ethylene concentration. Amer. J. Potato Res. 82:389-397.

Daniels-Lake, B.J., R.K. Prange, and J.R. Walsh. 2005b. Carbon dioxide and ethylene: A combined influence on potato fry color. HortScience 40:1824-1828.

Denny, F.E. and N.C. Thornton. 1940. Factors for color in the production of potato chips. Contrib. Boyce Thompson Inst. Plant Res. 11:291-303.

Poapst, P.A., A.B. Durkee, W.A. McGugan, and F.B. Johnston. 1968. Identification of ethylene in gibberellic-acid-treated potatoes. J. Sci. Food Agr. 19:325-327.

Prange, R.K., W. Kalt, B. Daniels-Lake, C.L. Liew, R.T. Page, J.R. Walsh, P. Dean, and R. Coffin. 1998. Using ethylene as a sprout control agent in stored 'Russet Burbank' potatoes. J. Amer. Soc. Hort. Sci. 123:463-469.

Rastovski, A. 1987. Storage losses, p. 177-180. In: Rastovski, A and A van Es (eds.). Storage of potatoes-Post-harvest behavior, store design, storage practice, handling, Pudoc, Wageningen, The Netherlands.

Schaper, L.A., M.T. Glynn, and J.L. Varns. 1993. Potato bin management based on respired $\mathrm{CO}_{2}$. Appl. Eng. Agr. 10:89-94.

Schouten, S.P. 1993. Influence of temperature and carbon dioxide content on sprout growth and fry color of different potato cultivars, p. 782-788. In: Blanpied, G., J. Bartsch, and J. Hicks (eds.). Proc. 6th Intl. Controlled Atmosphere Res. Conf., Ithaca, New York, USA, 15-17 June 1993, Northeast Reg. Eng. Services (NRAES)-71.

Suttle, J.C. 2003. Auxin-induced sprout growth inhibition: Role of endogenous ethylene. Amer J. Potato Res. 80:303-309. 